УДК 342.922

DOI https://doi.org/10.32837/pyuv.v0i1(30).530

O.P.Pадишевська
огсіd.org/0000-0002-3262-7487
кандидат юридичних наук,
ооцент кафедри адліністративного права
юридичного факультету
Київського національного університету ілені Тараса Шевченка,
суддл
Касаційного адліністративного суду в складі Верховного Суду

\title{
ДО ПИТАННЯ ПРО ПРЕДМЕТ АДМІНІСТРАТИВНОГО ПРАВА У ВІТЧИЗНЯНІЙ ТА ЕВРОПЕЙСЬКИХ ПРАВОВИХ ДОКТРИНАХ В УМОВАХ ТРАНСФОРМАЦІЙНИХ ЗМІН
}

Постановка проблеми. Усі галузі вітчизняного права переживають нині ренесанс, повертаючись до істинного розуміння своєї природи i призначення, переосмислюючи предмет, метод, систему, інструменти правового впливу на суспільні відносини. Нині триває не тільки узгодження 3 європейськими стандартами acquis $€ C$ національного законодавства, зокрема у сфері організації та функціонування публічної влади в державі, а й осучаснення української правової системи загалом. Це водночас зумовлює потребу подальшого «якісного» реформування діяльності публічної адміністрації із застосуванням норм права та запровадженням таких, які відповідали б сучасним реаліям, концептуальних підходів до осмислення появи нових, традиційно відомих правопорядку в європейських країнах, галузей, насамперед адміністративного права [1, с. 86]. Однак проведення реформи адміністративного права не є суто українською потребою. Це - загальна закономірність сучасного не тільки пострадянського, а й світового розвитку. Причому зарубіжний досвід показує, що подібні реформаційні завдання ніде не вирішувались шляхом проведення короткотермінових, «швидких» кампаній [2, с. 7].

Останніми роками вітчизняне адміністративне право, як і багато інших галузей права, піддалося серйозним трансформаціям, адже інтенсивна динаміка розвитку суспільних відносин в умовах європеїзації та глобалізації дає імпульси для правової матерії, які спрямовані на розвиток i вдосконалення, а також виявлення нових, інноваційних підходів до формування сучасної правової доктрини адміністративного права. Але якщо деякі з галузей традиційно зберегли свої «межі», засоби правового впливу і внутрішню побудову, зазнавши лише істотних змін нормативно-правового характеру, то адміністративне право зіткнулося з серйозними викликами. Сприйняття його як права, що обслуговує державні інтереси, поступово змінилося на те, що створює оптимальний режим взаємовідносин між особами і публічною адміністрацією з судовим контролем.

У таких умовах, за переконанням В. Авер'янова, вирішальне значення для формування нової національної доктрини адміністративного права має переосмислення фундаментальних засад теорії адміністративного права, найважливіша серед яких - наукове тлумачення предлета регулювання цієї галузі права (в загальновживаному визначенні - предмет адміністративного права). Адже саме завдяки цій основоположній категорії адміністративне право виокремлюється як самостійна галузь українського права і визначається сфера їі регулятивної дії [3]. Тож варто взяти на озброєння твердження С. Стеценка: «Проблематика визначення предмета адміністративного права потребує свого опрацювання, обміну думками серед науковців, визначення тенденцій та прогнозування напрямів розвитку. Як видається, це потрібно науці адміністративного права, це потрібно правозастосовній практиці, це важливо для навчального процесу» [4, с. 25].

Ступінь наукової розробки проблеми. Вчення про предмет адміністративного права і актуальність проблеми його переосмислення було $\mathrm{i}$ залишається під постійною увагою як дореволюційних, радянських, так і сучасних вчених (В. Авер'янова, М. Аржанова, Ю. Битяка, Е. Берендтса, I. Бойка, В. Галунька, I. Голосніченка, А. Єлістратова, Л. Коваля, Т. Коломоєць, В. Колпакова, Є. Курінного, Ю. Козлова, Р. Мельника, Г. Петрова, С. Стеценка, С. Студенікіна, Ц. Ямпольської та ін.). Незважаючи на історичну спадковість «тягаря» великої кількості наукових розробок у сфері окреслення предмета адміністративного права - сфери регулювання адміністративно-правових відносин, нині ця тематика набуває нового забарвлення та імпульсу: проводяться окремі міжнародні науково-практичні конференції [5], публікуються колективні монографічні дослідження, зокрема доволі показовими є напрацювання київської та харківської 
шкіл адміністративного права ${ }^{1}$ тощо. Переважно вони розвивають нову доктрину сучасного адміністративного права, розбудовують її на правовій концепції людиноцентризму, верховенства права та засадах ліберальної правової держави загалом. Однак, на наш погляд, важливим аспектом у таких дослідженнях має бути застосування порівняльно-правового методу наукового пізнання, що надасть нової якості для розвитку теорії адміністративно-правової науки, використовуючи європейський досвід розв' язання проблем її формування, особливо в умовах європеїзації права.

Результати дослідження. 3 погляду вітчизняної теорії права, предмет правового регулювання окремої галузі права є теоретичною дефініцією, яка відображає характеристики певного кола суспільних відносин, що регулюються нормами цієї галузі права [7, с. 44]. Проте застосування такого класичного підходу до відмежування галузей права нині наштовхується на певні труднощі, особливо під час визначення суспільних відносин, що становлять предмет адміністративного права України.

Свого часу А. Єлістратов у праці «Основні засади адміністративного права» (1917) сформулював концепцію адміністративного права, яка складалася $з$ таких частин: завдання та джерела адміністративного права; публічно-правові відносини та публічно-правова діяльність; система адміністративних установ; адміністративно-правові акти; способи забезпечення законності, адміністративна юстиція, адміністративна відповідальність [8, с. 86]. Як наслідок, вчений зробив висновок, що предметом регулювання адміністративного права є не адміністративна діяльність, а систела правовідносин (виділено нами. - O.P.), що виникають між приватними особами та владою. I саме ці суспільні відносини є ядром предмета регулювання адміністративного права та зумовлюють перетворення права поліцейського на адміністративне [9, с. 80]. Справді, право як регулятор суспільних відносин не може існувати поза суспільством, соціумом і суспільними відносинами, які в ньому виникають, змінюються та припиняються з об'єктивних або суб'єктивних чинників. Отже, є логічним висновок, що визначення адміністративного права можливе тільки на основі аналізу реальних суспільних відносин, які регулюються нормами чинного законодавства, крізь призму їхнього правозастосування та механізмів судового та позасудового захисту в разі порушення.

Виділяючи різні вітчизняні наукові підходи до розуміння предмета адміністративного права, потрібно зазначити, що їх кілька. Ірунтовний аналіз підходів здійснив Р. Мельник у статті «Новий погляд на «вічну» проблему: предмет адміністратив- ного права» [10, с. 38-46]. Так, дослідник групує позиції вчених, що визначають предмет цієї галузі, через сукупність суспільних відносин щодо: державного управління (публічного управління) економічною, соціально-культурною та адміністративно-політичною сферами, а також у процесі реалізації делегованих повноважень; діяльності органів виконавчої влади та органів місцевого самоврядування щодо забезпечення реалізації та захисту прав громадян і юридичних осіб і виконання покладених на них обов'язків; надання органами виконавчої влади та органами місцевого самоврядування різноманітних адміністративних (управлінських) послуг (публічно-сервісна діяльність); застосування заходів адміністративного примусу, зокрема адміністративної відповідальності; реалізації юрисдикції адміністративних судів; внутрішньоорганізаційної діяльності апаратів усіх державних органів, адміністрацій державних підприємств, установ та організацій; проходження державної служби або служби в органах місцевого самоврядування; розгляду судами справ про адміністративні правопорушення [10, с. 38-40].

Водночас окремо заслуговує на увагу, на наш погляд, комплексний підхід Т. Коломоєць, яка розглядає предмет сучасного адміністративного права як такий, що формується: 1) у процесі публічного адміністрування економічної, соціально-культурної та адміністративно-політичної галузей, а також під час реалізації повноважень органами місцевого самоврядування, громадськими організаціями та деякими іншими недержавними інституціями делегованих органами виконавчої влади повноважень; 2) у процесі діяльності органів виконавчої влади та органів місцевого самоврядування, їх посадових осіб щодо забезпечення реалізації та захисту в адміністративному порядку прав і свобод громадян, надання їм, а також юридичним особам, різноманітних адміністративних (управлінських) послуг; 3) у процесі внутрішньої організації та діяльності всіх державних органів, адміністрацій державних підприємств, установ та організацій, а також у зв'язку з публічною службою; 4) реалізації юрисдикції адміністративних судів і поновлення порушених прав громадян та інших суб'єктів адміністративного права; 5) під час застосування заходів адміністративного примусу, зокрема адміністративної відповідальності, щодо фізичних і юридичних осіб $[11$, с. 4]. Є. Курінний визначає його як «систему однорідних суспільних відносин регулятивного та охоронного, матеріального і процесуального характеру, в яких реалізуються права, свободи й обов'язки учасників владно-управлінської діяльності або адміністративно-правового захисту» [12, с. 34].

\footnotetext{
${ }^{1}$ До прикладу, статті сучасних адміністративістів, присвячені дискусійним питанням визначення кола і характеру відносин, що формують предмет адміністративного права, проблемам встановлення елементів структури цієї галузі (див. збірку «Питання адміністративного права» (Харків, 2018) [6]).
} 
Проте труднощі з визначенням предмета адміністративного права (і національного, і європейських країн) завжди супроводжували цю галузь. Це пов'язано з тим, що суспільні відносини, які регулюються адміністративним правом, настільки безмежні та ідеологічно «залежні», що не піддаються обліку і класифікації. Ще донедавна пострадянську модель адміністративного права пов'язували 3 колишньою «управлінсько-юрисдикційною» ідеологією, де людина позиціонувалася тільки як «об’єкт владарювання» $з$ боку держави, а не як головний адресат надання певних послуг, тобто не як суб'єкт, якому має «служити» держава [3].

В адміністративно-правовій науці європейських країн спроби сформулювати визначення адміністративного права здійснюється не через предмет правового регулювання, а за допомогою інших спеціальних критеріїв, підходів, «формул» - сфери адміністративно-правової діяльності або їх суб'єктів. Проте і в одному, і в іншому випадку варто констатувати, що воно не є статичним поняттям: постійно змінюється та модифікується, зокрема і під впливом процесів європеїзації та глобалізації. Адміністративне право трансформується з огляду на позитивні й негативні, «м'які» та «тверді» інструменти впливу, тому необхідно або надавати форму (дефініцію) галузі права, або шляхом характеристики предмета правового регулювання враховувати низку факторів (темпоральність, територіальність, політичну направленість, рівень правового культури, розвиток механізмів державного управління i державної служби, показники децентралізації влади і соціально-економічного рівня життя, стандарти захисту прав людини тощо).

Традиційним є підхід у зарубіжній науці адміністративного права, за яким адміністративне право розглядають у негативному і позитивному значеннях. Під першою категорією розуміють «право великої решти». Прикладами можуть бути визначення німецького вченого О. Майєра (O. Mayer) «де закінчується конституційне право, там починається адміністративне» [13], французького дослідника Г. Бребана (G. Braibant), який за основу предмета адміністративного права визначає державне управління, але вилучає 3 нього ті сфери, які не є об'єктом адміністративно-правового регулювання, наприклад, підприємницьку діяльність державних корпорацій, політичну діяльність тощо [14, с. 7], американського вченого Л. Фрідмена (F. Fridman), який до адміністративного сектору зараховує суспільні відносини за межами законодавчої, судової діяльності або діяльності президента, губернаторів, мерів, органів, що відають питаннями національної безпеки [15, с. 92], англійського науковця В. Вейда (W. Wade), який його ідентифікує з діяльністю і контролем за адміністративною владою [16, p. 4].
Водночас позитивна дефініція дає змогу відділити адміністративне право від інших галузей, особливо публічного права. Як критерій поділу тривалий час застосовували суб'єктний критерій - орган публічного адміністрування. Пізніше ву європейській фаховій літературі зустрічаємо предметний критерій - адміністративно-правову діяльність (публічне адміністрування), що поєднували із вказівками на метод правового регулювання, інструменти (форми) діяльності суб'єктів публічної адміністрації, адміністративно-правові відносини, характер публічних завдань, співвідношення публічного і приватного інтересу, систему адміністративного судочинства, цінності та функції, які притаманні адміністративному праву тощо [17, s. 44].

Під час застосування іншого критерію до формування дефініції адміністративного права суб'єктного - Е. Ура (E. Ura), пов'язуючи його, насамперед, з історичним розвитком публічної адміністрації, вказує, що норми цієї галузі права мають не тільки бути гальмами для влади, a, з огляду на важливість держави у реалізації публічних потреб суспільства та кожного його члена, бути двигуном такої діяльності. Адже адміністративне право має вказати на ті сфери, де необхідне втручання держави, визначити межі, порядок i спосіб діяльності суб'єктів публічної адміністрації, змінювати, за потреби, їх інституційну і функціональну площини [18, s. 26]. Проте на початку $\mathrm{XX}$ ст. такого визначення стало «замало», адже система інструментів діяльності публічної адміністрації розширилася, перед нею постали нові виклики і вимоги від приватних осіб.

У процесі застосовування предметного критерію до формулювання дефініції адміністративного права основний акцент робиться на його функціональній складовій частині: це сукупність норм, що регулює адміністративно-правову діяльність органів публічної влади. Проте і цей підхід не виконує свого основного завдання - надати комплексного бачення фундаментальній галузі права, якою є адміністративне право. Його критики вказують на надто широке тлумачення поняття «адміністративно-правова діяльність», що може бути предметом регулювання й інших галузей права.

Найбільш комплексною у польській адміністративно-правовій науці тривалий час вважалася дефініція адміністративного права, яку запропонував ще у 1978 р. Я. Старосчак (J. Staro ciak): це «галузь права, норми якої регулюють діяльність державних органів, що здійснюється для виконання визначених у законі завдань через форми їхньої діяльності <...> Осердям цієї галузі права $€$ норми, що можуть викликати виникнення адміністративно-правового відношення» [19, с. 17-18]. Адже таке визначення поєднувало три підходи: по-перше, суб'єктний; по-друге, предметний; 
по-третє, інструменти (форми) діяльності. У той самий історичний період, розкриваючи дуалістичну природу адміністративного права (як правових засад, що регулюють позасудову діяльність держави (державних органів), спрямовану на досягнення державних цілей, а також як систему правових норм, які регулюють правове відношення між державою та підпорядкованими їй особами), Ю. Панейко виділяє предметом адміністративного права сферу регулювання організації та діяльності публічної адміністрації [20, с. 119].

В європейській науці адміністративного права також застосовується й інший підхід до розкриття сутності адміністративного права - широке та вузьке розуміння. Так, «широку» дефініцію надає Я. Ланг (J. Lang) - «це сукупність правових норм, що регулюють організацію і діяльність публічної адміністрації як частину державного апарату, а також дії приватних осіб та інших суб'єктів, які не регулюються нормами інших галузей права» [21, с. 21]. Водночас «вузька» дефініція охоплює сукупність норм, що: а) встановлюють повноваження суб'єктів публічної адміністрації чи адміністративно-правовий статус приватних осіб, де чітко вказано на їхню діяльність, їхнє публічне майно чи можливість прийняття адміністративних актів; б) надають змогу делегувати владно-управлінські повноваження суб'єктам «ззовні»; в) забезпечують право суб'єктів «ззовні» вимагати від суб'єктів публічної адміністрації виконання своїх зобов'язань, зокрема через надання публічних послуг чи об'єктів державної та комунальної власності у користування приватним особам, дозволів на ведення господарської діяльності чи виїзду за кордон тощо [21, s. 30-31].

Зрозуміло, що адміністративне право країн посткомуністичного табору, зокрема й України, тривалий час розвивало саме перший напрям - управлінське право, що виконує, насамперед, регулятивну функцію. Проте зі зміною правової ідеології, що лежить в основі адміністративного права, артикуляції на охоронній і процедурній функціях, а також загальної гуманізації права підхід до визначення, чим є адміністративне право, змінився. Так, сучасна польська дослідниця 3. Дунєвска (Z. Duniewska) пропонує розглядати адміністративне право, норми якого стосуються: 1) створення, організаційної структури, завдань і принципів діяльності суб'єктів публічної адміністрації та інших органів, що виконують владно-управлінські функції для задоволення загального добра (публічного інтересу) та колективних інтересів фізичних осіб; 2) відносин, що виникають між такими суб'єктами; 3) прав та обов'язків суб'єктів публічної адміністрації, діяльність яких підлягає судовому і позасудовому контролю [17, s. 40].
На противагу класичним поглядам на адміністративне право і його предмет, в Європі нині спостерігаються нові тенденції щодо його характеристики. Так, новаторською тривалий час вважалася «кермувальна» концепція німецького вченого Е. Шмідта-Ассманна (E. Schmidt-A mann), за якою адміністративне право має реалізувати ідею повного «неспеціалізованого» врегулювання, правопорядку, що вимагає нового догматичного і методологічного обгрунтування, адже воно є не тільки правом, що регулює втручальне адміністративне адміністрування, але й публічно-адміністративну діяльність із надання адміністративних послуг, права одержання інформації та прийняття рішень адміністративних органів; охоплює усю палітру публічно-адміністративної діяльності, тобто їі зовнішні та внутрішні зв'язки, контакти з громадянами з різних питань; воно не обмежується перспективою судового правового захисту, а охоплює такі сфери, яких не досягає його зонд [22, с. 18-19].

Новітнім поглядом на тлумачення поняття «адміністративне право» також є використання інструментів економічної науки, які розуміють публічну адміністрацію як надавача послуг, а фізичну особу -як набувача такої послуги (клієнта). Ще інша концепція фокусує увагу на тому, що виконання завдань органів публічної адміністрації має бути надане суб’єктам приватного права, а ще інша - теорія держави мережі - вказує, що всі суб'єкти - державні, муніципальні, приватні -€ партнерами публічного адміністрування. Варто підтримати таку думку Я. Зіммерманна: (J.Zimmermann): «За цією множинністю підходів до розкриття сутності адміністративного право не можна загубити «зерна», яке було посіяно майже два століття тому, і ніщо, наразі, не може його замінити; якщо воно перестане функціонувати як регуляторний та охоронний інструмент реалізації прав людини у публічно-правовій сфері, то стане регулятором господарської діяльності суб'єктів публічного і приватного права, що може й забути про людину» [23, s. 57].

Отже, питання визначення змісту адміністративного права як галузі національної системи права пов'язане, передусім, із питанням окреслення предмета галузі: визначивши предмет, визначимо, що таке адміністративне право. Проте, якщо візьмемо за основу, що таким предметом правового регулювання є діяльність або(i) суб'єкти публічної адміністрації, то повертаємося до складного питання, що порушується у вітчизняній науці адміністративного права: «Що таке публічна адміністрація та публічне адміністрування?» Проте узагальнено вкажемо, що це сукупність суб'єктів і органів, діяльність яких спрямована на реалізацію публічної влади 
шляхом виконання приписів законодавчих та підзаконних нормативно-правових актів для задоволення публічних інтересів. У такому разі до предмета адміністративного права доцільно було б зараховувати і діяльність суб'єктів публічної адміністрації, а також систему цих органів.

Проте потрібно усвідомлювати, що нині поняття «публічна адміністрація» в європейській і вітчизняній доктрині є надзвичайно мобільним: йде переосмислення як змісту цього поняття, так і завдань, які стоять перед нею, а це постійно змінює предмет адміністративного права. Недарма Є. Супернат (J. Supernat) вказує на можливі проблеми в майбутньому для законодавця, адже «сучасна публічна адміністрація - це і «центр» адміністративних договорів, і адміністрування за допомогою третіх осіб, і спільна діяльність суб’єктів публічного і приватного права для вирішення публічних справ і забезпечення публічного інтересу, і відповідь на діджиталізацію (цифрову революцію)» [24, с. 162$]$.

Вагомим чинником, що нині впливає на ре(формування) адміністративного права, також є процес глобалізації, з активним поступом якого публічна адміністрація набуває інших характеристик, завдань та цілей. Футурологічною видається нині концепція, за якою адміністративне право втрачає позиції фундаментальної галузі публічного права, якій притаманний імперативний метод правового регулювання (влади та підпорядкування), адже глобальне адміністративне право передбачає створення мереж адміністративних органів, основним інструментом (формою) діяльності яких є укладання адміністративних договорів та приватноправове партнерство. Тому логічно, що адміністративне право нині (з публічною адміністрацією як предметом правового регулювання) і адміністративне право в перспективі 20-30 років (із модифікованою глобальною публічною адміністрацією) - це різні за змістом галузі права, з різним предметом правового регулювання [25, s. 22].

Тому вчені Р. Мельник [10] та Я. Зіммерманн (J. Zimmermann) пропонують взагалі відійти від позиції, що науці потрібен предмет адміністративного права, що він є критерієм відмежування різних галузей права, «є тією аксіомою, що може застосовуватися до усіх елементів національної системи права <...> це є позитивістським баченням того, чим $є$ право, що нині не оправдовує свого змісту» [25, s. 24]. Останній обгрунтовує, що для дефініціювання адміністративного права й окреслення сфери впливу його норм необхідно звертатися до визначення ознак, притаманних адміністративному праву: публічність, людиноцентризм, безспірність, динамічність, загальнообов'язковість (ius cogens) тощо [23, s. 59-71].
Як наслідок, у новітній вітчизняній і європейській фаховій літературі дослідники часто аналізують доробок інших колег, не намагаючись надати власного бачення. Навіть висловлюється думка, що «цей процес є неосяжним <...> жодне визначення не охопить всіх структурних елементів адміністративного права, не буде панацеєю на усі «хвороби» юристів» [26, с. 9], «жодна з дефініцій не є помилковою, адже їх можна застосувати у конкретних випадках, для досягнення певного дослідницького результату <...> але вони можуть бути i «пустими», якщо не враховувати в них певного історичного досвіду <...> його не можна окреслити в абсолютний, закритий спосіб» [27, с. 18]. Тому, як не дивно, адміністративне право тривалий час було і залишається недоокресленим - галуззю «невизначеної правової матерії», хоча супроводжує людину від моменту народження до моменту смерті.

Висновок. Узагальнено можемо стверджувати, що думки, висловлені дореволюційними вченими про те, що адміністративне право - це сукупність норм, «за допомогою яких держава творить умови для багатостороннього розвитку суспільства» [28, с. 14], є актуальними нині для української адміністративно-правової доктрини. Адже вітчизняна модель сучасного адміністративного права у частині визначення його предмета повністю відповідає тенденціям розвитку адміністративного права європейських демократичних держав, що проявляється в зміні підходів до тлумачення змісту адміністративного права і безрезультативності намагань сформулювати його дефініцію. Таке твердження грунтується на низці характеристик, що мають спільну природу в європейських країнах континентальної правової системи, об’єднаних концепцією європеїзації сучасного адміністративного права.

\section{Jimepamypa}

1. Константий О. До питання поняття, предмета, методу і системи адміністративного судочинства України. Піәприємництво, господарство $і$ право. 2019. № 8. С. $86-90$.

2. Адміністративна реформа для людини: науково-практичний нарис / за заг. ред. І.Б. Коліушка. Київ, $2001.72 \mathrm{c}$.

3. Авер'янов В. Нові риси предмета українського адміністративного права. Персонал. 2005. № 4. С. 76-81.

4. Стеценко С.Г. Сучасний погляд на предмет адміністративного права. Публічне право. 2016. № 1 (21). C. 20-26.

5. Предмет правового регулювання галузей вітчизняного права : матеріали Міжнар. наук.-практ. конф., м. Київ, 15-16 берез. 2019 р. / ред. кол.: І. Гриценко, Р. Мельник та ін. Київ : Вид. дім «Гельветика», $2019.90 \mathrm{c}$.

6. Питання адміністративного права. Кн. 2 / відп. за вип. Н.Б. Писаренко. Харків : 000 «Оберіг», 2018. 182 c. 
7. Загальна теорія права : підручник / М. Козюбра, С. Погребняк, О. Цельєв, Ю. Матвєєва; за заг. ред. М. Козюбри. Київ : Ваіте, 2016. 392 с.

8. Елистратов А.И. Основные начала административного права. 2-е изд. Москва : Издание А.Г. Лемана, 1917. 294 c.

9. Вопросы административного права / под ред. А.И. Елистратова. Кн. 1. Москва : Т-во Тип. А.И. Мамонтова, 1916. $195 \mathrm{c}$.

10. Мельник Р. Новий погляд на «вічну» проблему: предмет адміністративного права. Питання адліні стративного права. Кн. 2 / відп. за вип. Н.Б. Писаренко. Харків : 000 «Оберіг», 2018. С. 33-53.

11. Адміністративне право України : підручник / за заг. ред. Т.О. Коломоєць. 2-ге вид., змін. і допов. Київ : Істина, 2012.528 с.

12. Курінний Є.В. Предмет і об'єкт адміністративного права України : монографія. Дніпропетровськ : Юрид. акад. М-ва внутр. справ; Ліра ЛТД, 2004. 340 с.

13. Maurer H. Ogólne prawo administracyjne / tł. i red. nauk. K. Nowacki; współpr. A. Kisiel, M. Rynkowski. Wrocław : Kolonia Limited, 2003. $246 \mathrm{~s}$.

14. Брэбан Г. Французское административное право / пер. с фр.; под ред. и со вступ. ст. С.В. Боботова. Москва : Прогресс, 1988. 488 с.

15. Фридмэн Л. Введение в американское право / пер. с англ.; под ред. М. Калантаровой. Москва : Прогресс, 1993. 286 c.

16. Forsyth C.F., Wade W. Administrative Law Oxford : Oxford University Press, 2014. 867 p.

17. Prawo administracyjne. Pojęcia, instytucje, zasady w teorii i orzecznictwie / Z. Duniewska, B. JaworskaDęsska, R. Michalska-Badziak, E. Olejniczak-Szałowska; red. M. Stahl. Wyd V. Warszawa: Lex, 2013. $517 \mathrm{~s}$.

18. Ura E., Ura E. Prawo administracyjne. Wyd. VII. Warszawa, 2008.618 s.

19. Starościak J. Prawo administracyjne. Warszawa, 1977. $140 \mathrm{~s}$.

20. Наука адміністрації й адміністративного права. Загальна частина (за викладами професора Юрія Панейка) / уклад.: В. Бевзенко, І. Коліушко, О. Радишевська, І. Гриценко, П. Стецюк. Київ : ВД «Дакор», 2016. 464 c.

21. Jagielski J., Lang J., Szubiakowski M., Wiktorowska A. Prawo administracyjne; red. M. Wierzbowski. Wyd. XIII. Warszawa, 2017. $736 \mathrm{~s}$.

22. Шмідт-Ассманн Е. Загальне адміністративне право як ідея врегулювання: основні засади та завдання систематики адміністративного права / пер. 3 нім. Г. Рожков, I. Сойко, А. Баканов; ред. О. Сироїд. 2-ге вид., переробл. та допов. Київ : «К.I.C.», 2009. 552 с.

23. Zimmermann J. Prawo administracyjne. W. VIII. Warszawa, 2018. $589 \mathrm{~s}$.

24. Supernat J. Administracja jako splot umów. Umowy $w$ administracji ; red. J. Boć, L. Dziewięcka-Bokun. Wrocław, 2008. $546 \mathrm{~s}$.

25. Zimmermann J. Aksjomaty prawa administracyjnego. Warszawa : Lex a Wolters Kluwer bussiness, 2013. $310 \mathrm{~s}$

26. Zimmermann M. Z zagadnień definicji prawa administracyjnego. Acta Universitatis Wratislaviensis. Prawo XII. 1964. № 19. S. 7-14.

27. Boć J., Jeżewski A., Szadok-Bratuń J. Prawo administracyjne / red. J. Boć. Wyd. 12. Wrocław, 2007.675 s.

28. Okolski A. Wykład prawa administracyjnego oraz prawa administracyjnego obowiązującego w Królestwie Polskiem. Warszawa : Redakcja Biblioteki Umiejętności Prawnych, 1880. T. 1. 244 s.

\section{Анотація}

Радишевська О. Р. До питання про предмет адміністративного права у вітчизняній та європейських правових доктринах в умовах трансформаційних змін. - Стаття.

У статті розглянуто предмет адміністративного права у вітчизняній та європейських правових доктринах в умовах трансформаційних змін. Зазначено, що вітчизняне адміністративне право, як і багато інших галузей права, піддалося серйозним трансформаціям, адже інтенсивна динаміка розвитку суспільних відносин в умовах європеїзації та глобалізації дає імпульси для правової матерії, які спрямовані на розвиток і вдосконалення, а також виявлення нових, інноваційних підходів до формування сучасної правової доктрини адміністративного права України. Акцентовано на мобільності поняття «публічна адміністрація", яка змінює предмет адміністративного права, а також неможливості сформувати визначення цій галузі права. Наголошено, що визначення адміністративного права можливе тільки на основі аналізу реальних суспільних відносин, які регулюються нормами чинного законодавства, крізь призму їхнього правозастосування та механізмів судового та позасудового захисту в разі їх порушення. Зроблено висновок, що вітчизняна модель сучасного адміністративного права у частині визначення його предмета повністю відповідає тенденціям розвитку адміністративного права європейських країн відкритого типу. На формування його предмета в державах-членах Ради Європи (ЄC) вплинули дуалізм публічної адміністрації (поєднання управлінської складової частини із сервісною), гуманізація права загалом й адміністративного права зокрема, підвищена увага до механізмів судового захисту прав людини (діяльності адміністративних судів), глобалізація, що проявляється в побудові мережевої адміністрації на основі договірних відносин; європейська інтеграція 3 третіми країнами, європеїзація (вплив ідей, принципів, підходів, що характерні для європейського адміністративного права та європейських країн).

Ключові слова: європеїзація, глобалізація, адміністративне право, предмет правового регулювання, правова система.

\section{Summary}

Radyshevska $O$. R. To the issue of formation of subject of administrative law in national and European legal doctrines in the context of transformational change. - Article.

The article deals with the issue of formation of subject of administrative law in Ukrainian and European legal doctrines in the context of transformational changes. It is noted that the national administrative law like many other branches of law has undergone serious transformations that connected to intensive development of public relations in the context of Europeanization and globalization. This gives impact to the legal matter which is aimed to reform and improve, and discover new, innovative approaches to the formation of modern legal doctrine of administrative law. The author emphasizes that the notion of "public administration" is very flexible and as a result it changes the subject of administrative law and proof the inability to formulate the definition of this branch of law. To complete this task we need to take to the account that this is possible to do only on the basis of the analysis of real social relations which are regulated by current legislation through the prism of their enforcement and the mechanisms of judicial and non-judicial protection in case of their violation. It is concluded that the national 
model of modern administrative law in terms of defining its subject fully corresponds to the tendencies of development of administrative law of European countries of open type (the Member States of the Council of Europe and the EU). There are influenced by: the dualistic nature of public administration (the combination of public management and public services); humanization of law in general, administrative law in particular; increasing attention to the mechanisms of judicial protection of human rights (administrative courts); the process of globalization; the process of European integration with third countries; the process of Europeanization (influence of ideas, principles, approaches and models that are characteristic to the European counties and European administrative law).

Key words: Europeanization, globalization, administrative law, subject of legal regulation, legal system. 